быть связано с местом этого концепта в ценностной картине мира и его взаимодействием с другими моральноэтическими ценностями народа.

Ключевые слова: концепт, концептуальный признак, объективация концепта, номинативное поле.

Rys Larysa, Yakymchuk Maksym. Lexicographic Representation of the Concept FRIEDEN in Modern German. The article deals with the analysis of the concept FRIEDEN and linguistic means of its verbalization in modern German. The material of lexicographic sources - explanatory, etymological and synonym dictionaries is systematized. Language means that characterize the concept and its features such as a main word that represents the concept in the language, derivatives of the concept's nominations, synonyms, stable phrases, which include the concept's name, dictionary definitions are established and the nominative field oh the concept FRIEDEN is modeled.

The concept FRIEDEN belongs to universal concepts. Three its dimensions can be distinguished: it can denote the peaceful coexistence of various states (global, interstate dimension), harmonious coexistence with other people (social dimension) and inner peace and harmony of a person with himself (individual dimension). Based on the etymological analysis, the etymological feature of the concept FRIEDEN which underlies its formation is determined: "a state of protection, of caring, friendly attitude towards others", which has transformed in modern definitions into a state of harmony with oneself and others.

As a content of concepts is close to the content of the concept main word's dictionary definition, lexicographic analysis and distributional analysis of the concept name are carried out, and the main features of the concept FRIEDEN which are related to its conceptual component are established. The basic conceptual features are considered to be: life / state of internal and interstate coexistence without war or other hostilities; a state of harmony; a state of serenity; peace treaty, agreement between the parties; a condition characterized by a certain duration and territory of distribution. A close connection between the concept FRIEDEN and the binary opposed concept KRIEG is revealed.

The great importance of the concept FRIEDEN both for society and for individuals is established. The peace is a great value, which can be of a relative nature, as evidenced by individual lexical units that serve to verbalize the concept, and have a negative connotation, which may be related to the place of this concept in the value picture of the world and its interaction with other moral and ethical values of the people.

Keywords: concept, conceptual feature, verbalizing of the concept, nominative field.

DOI: https://doi.org/10.32782/2410-0927-2020-12-27

УДК 811.133.1'42:82-3(045)

Руслана Савчук

\title{
ФРАНЦУЗЬКИЙ ОНІРИЧНИЙ НАРАТИВ: ДОСВІД ЛІНГВОСЕМІОТИЧНОГО АНАЛІЗУ (НА МАТЕРІАЛІ РОМАНУ Ж. ДЕ НЕРВАЛЯ “AURÉLIA OU LE RÊVE ET LA VIE”)
}

У статті представлені та проаналізовані найбільш показові лінгвонаративні і лінгвокогнітивні механізми конструювання оніричної оповіді, віднайдені у французькому художньому текстотворенні ХІХ століття. 3’ясування текстотвірного потенціалу “змінених станів свідомості” як знаково-мовних структур відображення наративних стратегій у французьких прозових творах дає змогу простежити динаміку наративного мислення письменників як представників певної історико-культурної епохи. Французькі прозові твори XIX століття є тими зразками художнього мислення письменників, які відображають суспільні настрої в кожну історичну добу, а тому аналіз їх мовотворчих потенцій $є$ необхідним для реконструкції механізмів трансформації когнітивних структур у знакові мовні форми. 3 метою визначення прикметних тенденцій у формуванні та форматуванні оніричного наративу означеного вище проміжку часу з'ясовані головні закономірності породження та розгортання оповіді в аспекті образно-стилістичної фігуративності в плані семіозису наративних прийомів, технік або тактик французького художнього текстотворення. Із позицій лінгвонаратології, лінгвосеміотики, а також із залученням здобутків семантики можливих світів і стилістики художнього мовлення з'ясовано, що французьке художнє текстотворення XIX століття відзначається побудовою та форматуванням оніричної оповідної реальності, яка характеризується множинністю, метафоричністю, фантастичністю та емоційно-смисловою значущістю оповідного зображення. 3 погляду лінгвосеміотичного підходу стрижневою ознакою французького художнього наративу XIX ст. $\epsilon$ “"змінені стани свідомості” письменника, які виступають референтами відображення та конструювання оніричної оповідної реальності. У пропонованій статті з'ясовано, що французький оніричний наратив вибудувано в дискурсі сновидінь $\mathrm{i}$ сонних візій гомодієгетичного оповідача, що співвідноситься 3 мовною особистістю самого французького письменника. Установлено, що в розглядуваному романі “Aurélia ou le rêve et la vie” текстуальними засобами творення квазіреальності виступають оніричні лексеми та численні засоби образно-стилістичної фігуративності із семою ‘уявне / неможливе'.

Ключові слова: оніричний наратив, онірична оповідна реальність, лінгвосеміотика, французьке художнє текстотворення, змінені стани свідомості.

(C) Савчук P., 2020 
Вступ. Одним із найбільш виразних способів конструювання оніричної оповідної реальності в лінгвонаративній поетиці французького письменника XIX століття Жерара де Нерваля є дискурс сновидінь і сонних візій, що вибудовують і засвідчують особливу і дуже специфічну індивідуально-авторську картину уявлень про світ, яка виступає генератором його складного й неординарного за своїми характеристиками художнього макрокосму.

Наративний дискурс сновидінь і сонних візій (la ligne du rêve-vision [12, с. 2]) як світ, у якому перебуває персонаж - гомодієгетичний оповідач і який породжується іншим світом світом божевілля, постає водночас простором гностичної правдивості для самого письменника [там само, с. 3], зважаючи на той факт, що Жерар де Нерваль перебував певний час на лікуванні у зв'язку із загостренням психічних розладів [14]. Беручи за основу власний досвід галюцинацій і марень, автор вибудовує наративний дискурс сновидінь і сонних візій як деякий квазіреальний світ гомодієгетичного оповідача, що є онтодосяжним (за Г. В. Новиковою) [15; 16, с. 7-11] завдяки можливостям хворої уяви або зміненим станам свідомості французького письменника. Гомодієгетичний оповідач, за яким криється сам автор, перетворює себе на об'єкт розвідки, оповідаючи про різні прояви свого хворобливого стану.

Актуальність пропонованої статті зумовлена іï спрямуванням на пошук нових інтерпарадигмальних підходів до інтерпретації художнього тексту з поглибленою увагою до двох основних аспектів твору, а саме когнітивного і семіотичного, що найбільш показово пов'язані з такими категоріями, як свідомість / мислення і художнє мовлення. Метою цієї наукової праці є розкриття сутності оніричного наративу з позицій лінгвосеміотики в контексті окреслення стрижневих лінгвокогнітивних наративних тенденцій у французькому художньому текстотворенні XIX ст.

Предмет дослідження складають, таким чином, лінгвонаративні й лінгвокогнітивні параметри оніричної оповідi у французькому художньому текстотворенні вказаного проміжку часу, серед яких ключову увагу віддано текстуальним засобам творення квазіреальності або, точніше сказати, оніричної реальності як таким, що найбільш повно розкривають сутність лінгвокогнітивних наративних стратегій художнього текстотворення досліджуваної історикокультурної доби. Об'єктом вивчення є французький оніричний наратив XIX ст.

Методи та методики дослідження. Лінгвосеміотичний аналіз наративу грунтується на методиці діалогічної інтерпретащії художнього твору, що постає сукупністю процедур аналізу тексту як знакового посередника дискурсу з урахуванням позамовних чинників текстової комунікації та інтегрованого принципу діалогічності [17, с. 533]. У цьому разі саме вихідне положення про діалогічність прозового тексту в координатах його комунікативної структури, започатковане і найповніше розроблене М. М. Бахтіним [1], надає змогу трактувати художній твір крізь призму його знакового характеру.

Крім того, підгрунтям лінгвосеміотичного аналізу є позиціонування семіотики в сучасних інтерпарадигмальних розвідках як особливого модусу мислення [2, с. 6] або справжньої метанауки чи науки наук [там само, с. 8], що представляє собою синтез окремих дисциплінарних досліджень знака [там само]. Власне лінгвосеміотичний аналіз, сутнісні елементи та процедури якого найповніше розкриті Ю. М. Лотманом $[10 ; 11]$, уможливлює розгляд художнього наративу як одного з феноменів культури, що формує своєрідну матрицю у творенні можливих варіантів існування дійсного світу [11, с. 102] з огляду на довільність використання письменниками мовних знаків у побудові певної оповідної реальності.

Лінгвосеміотичний аналіз (за О. Є. Бразговською) [2] використовуємо для виявлення семіотичних механізмів полікодової множинності смислів в оніричній реальності, вибудованій у розглядуваному художньому тексті.

Так, лінгвосеміотичний аналіз програмує опис діалогічних відношень тексту i комунікантів із інтеріоризованим (текстовим) буттям шляхом вияву кореляцій можливого світу оповіданих у творі подій та/чи дій із реальними подіями або фактами біографії адресанта, а також з урахуванням значущості художнього наративу для епохи його породження та рецепції $[17$, c. 535$]$. 
У цій науковій праці процедури розкриття процесів i механізмів французького художнього текстотворення XIX ст. із позицій лінгвосеміотики об'єднали лінгвосеміотичний аналіз і методику моделювання можливих світів (за Г. В. Новиковою) [15; 16], що дало змогу представити семіозис мовотворчих практик французького письменника у процесі конструювання трансформації онтології дійсного світу в оніричний. Такими знаково-мовними структурами реалізації лінгвокогнітивних наративних стратегій художнього текстотворення у наративі XIX ст. є “змінені стани свідомості” письменника.

Таким чином, лінгвосеміотичний етап вивчення текстуальних засобів творення оніричної реальності у французькому художньому наративі XIX ст. передбачає реалізацію двох основних дослідницьких процедур: 1) окреслення образно-стилістичної фігуративності оніричного наративу у плані семіозису наративних прийомів, технік або тактик художнього текстотворення; 2) виявлення текстотвірного потенціалу “змінених станів свідомості” як знаково-мовних структур відображення наративних стратегій у французькому художньому текстотворенні вказаної доби.

Беручи за відправні ідеї психоаналітичну концепцію 3. Фройда, К.-Г. Юнг запропонував теорію “глибинної психології”, згідно з якою сновидіння розвиваються як провісники майбутніх тенденцій розвитку особистості, як відображення несвідомого, колективного “родового” досвіду [8, с. 377].

У термінах психоаналізу поняття несвідомого значно ширше, ніж поняття підсвідомого $[13$, с. 26], що охоплює людські потяги та інстинкти й постає складовою несвідомого. Сфера ж останнього поширюється на явища незрівнянно вищі та вартісніші у внутрішньому світі людини [7, с. 58], а тому в цьому разі слід задіювати термін “надсвідоме" [13, с. 26], яким позначають ясну свідомість на противагу підсвідомому й неусвідомлюваному [7, с. 283].

Якщо взяти за вихідне постулат про те, що несвідоме передає інформацію інтелекту за посередництвом символів, то сни - це справжня динамічна мозаїка, що складається з символів, які виражають рух, конфлікт, взаємодію і розвиток великої енергетичної системи несвідомого [6, с. 29].

Результати та дискусії. 3 позицій лінгвосеміотичного аналізу текстовим референтом світу божевілля є хвороба письменника, а текстуальними знаками, що маркують в оповіді інший, оніричний вимір персонажного буття, виступають такі семантичні одиниці, як impression n.f., maladie n.f., mystère n.m., délire n.m., які об'єднуємо навколо спільного інваріантного значення: 'état d'une personne caractérisé par une perte du rapport normal au réel et un verbalisme qui en est le symptôme (виділено авторкою. - Р.С.) pouvant être provoqué par une cause physiologique ou physique' [4], а отже, змінених станів свідомості як імовірної втрати зв'язку з реальністю.

Визнаючи сновидіння складовими несвідомого в психології творчого процесу [13, с. 28], у текстології висувається концепція інтуїтивної, несвідомої та натхненної Богом творчості [там само, с. 39], завдяки якій несвідоме моделюється й вербалізується в ії активному стані, тобто в сновидінні, що походить із вищих, непізнаних розумом сфер [там само, с. 29]. Творча уява межує в цьому разі з інтуїтивними прозріннями, а божевілля трактується як вияв несвідомого, а отже, представляє собою свідомість, яка виходить за власні межі [19, с. 174].

Саме в такий спосіб із середини хворої свідомості (онтодосяжсний можливий авторський світ) моделюється онірична реальність персонажа, яка розкриває індивідуально-авторське світобачення й світовідчування, i саме через наративний дискурс сновидінь і сонних візій читач наближається до знайомства із неоднозначним, повним химер і незрозумілих страхів внутрішнім життям [13, с. 51] французького письменника:

Le rêve est une seconde vie. Je n'ai pu percer sans frémir ces portes d'ivoire ou de corne qui nous séparent du monde invisible. Les premiers instants du sommeil sont l'image de la mort; un engourdissement nébuleux saisit notre pensée, et nous ne pouvons déterminer l'instant précis où le moi, sous une autre forme, contunue l'oeuvre de l'existence. C'est un souterrain vague qui s'éclaire peu à peu, et où se dégagent de l'ombre et de la nuit les pâles figures gravement immobiles qui habitent le séjour des limbes. Puis le tableau se forme, une clarté nouvelle illumine et fait jouer ces apparitions bizzares; le monde des Esprits s'ouvre pour nous (Nerval, p. 1). 
У цитованому фрагменті оніричного наративу через денотативні й варіантні значення іменників і прикметників із семою 'уявне / неможливе', а саме rêve n.m., invisible adj., sommeil n.m., image n.f., nébuleux adj., bizarre adj., означується (квазі)онтодосяжсний світ, тобто світ реальної потенційності, що імплікується такими метафорами, як le rêve est une seconde vie (“сон - це друге життя”) (тут і далі переклад авторки. - Р.С.), les premiers instants du sommeil sont l'image de la mort ("перші хвилини сну - це образ смерті"), un engourdissement nébuleux saisit notre pensée (“туманне заціпеніння охоплює наш розум"), un souterrain vague qui s'éclaire peu à реи (“підземелля, в якому потрохи з'являються проблиски світла").

Зважаючи на те, що аналізований роман написано письменником під час його перебування в клініці через серйозний психічний розлад, можемо припустити, що за певних умов, а саме у змінених станах свідомості, зокрема внаслідок хвороби, Ж. де Нерваль вибудовує такий наративний дискурс сновидінь $i$ сонних візій, який набирає рис не лише можливого або альтернативного, але й дійсного стану буття. У цьому разі емерджентний ірреальний світ суперечить реальному, але з огляду на те, що його просто не існує в іншому вигляді для французького митця, ми класифікуємо останній як (квазі)онтодосяжний.

В оніричному наративі сон осягається гомодієгетичним оповідачем як деякий перехід, оскільки він відкриває нові можливості власного буття, що в оповіді експліковано стилістичною фігурою висхідної градамฺï: un engourdissement nébuleux saisit notre pensée $\rightarrow$ un souterrain vague qui s'éclaire peu à peu $\rightarrow$ se dégagent les pâles figures gravement immobiles $\rightarrow$ le tableau se forme, une clarté nouvelle illumine et fait jouer ces apparitions bizzares $\rightarrow$ le monde des Esprits s'ouvre pour nous. Наведений вище стилістичний засіб виразності підвищує емоційно-смислову значущість можливого стану буття оповідача як певного одкровення, зважаючи на семантичний інваріант текстової одиниці esprit n.m.: ‘être immatériel, incorporel' [4]: le monde des Esprits s'ouvre pour nous.

Через семантичні інваріанти таких дієслів, як saisir v.tr., s’éclairer v.pron., se dégager v.pron., s'ouvrir v.pron. у поєднанні з іменниками pensée n.f., clarté n.f. і monde n.m., імпліковано чітку паралель між станом переходу до іншого світу та сном, а саме 3 його чотирма послідовними фазами (un engourdissement nébuleux saisit notre pensée :: зменшується альфа-ритм, з'являються низькоамплітудні повільні дельта- й тета-хвилі, людина перебуває в стані дрімоти, ймовірні напівсонні галюцинації або марення $\rightarrow$ un souterrain vague qui s'éclaire peu à peu :: зароджується сигма-ритм і прискорений альфа-ритм, має місце відключення свідомості $\rightarrow$ se dégagent les pâles figures gravement immobiles :: додаються повільні високоамплітудні дельтаколивання $\rightarrow$ le tableau se forme, une clarté nouvelle illumine et fait jouer ces apparitions bizzares :: стадія найглибшого сну, переважають дельта-коливання $\rightarrow$ le monde des Esprits s'ouvre pour nous деяке одкровення, оскільки саме на цій стадії виникають сновидіння й можливі напади лунатизму й кошмари). Відтак, маємо аналогію між сном як фізіологічним процесом і сном як переходом до іншого - оніричного світу.

$<>$ Pendant la nuit qui précéda mon travail, je m'étais cru transporté dans une planète obscure où se débattaient les premiers germes de la création. Du sein de l'argile encore molle s'élevaient des palmiers gigantesques, des euphorbes vénéneux et des acanthes tortillées autour des cactus; les figures arides des rochers s'élençaient comme des squelettes de cette ébauche de création, et de hideux reptiles serpentaient, s'élargissaient ou s'arrondissaient au milieu de l'inextricable réseau d'une végétation sauvage. La pâle lumière des astres éclairait seule les perspectives bleuâtres de cet étrange horizon; cependant, à mesure que ces créations se formaient, une étoile plus lumineuse y puisait les germes de la clarté. Puis les monstres changeaient de forme, et dépouillant leurs premières peaux, se dressaient plus puissants sous des pattes gigantesques; l'énorme masse de leurs corps brisait les branches et les herbages, et, dans le désordre de la nature, ils se livraient des combats auxquels je prenais part moi-même, car j'avais un corps aussi étrange que les autres (Nerval, p. 34-36).

У поданому вище фрагменті наративний дискурс сновидінь $i$ сонних візій уводиться конотативно: la pâle lumière des astres éclairait seule les perspectives bleuâtres de cet étrange horizon; une étoile plus lumineuse y puisait les germes de la clarté через поєднання денотативних значень іменників lumière n.f.: 'ce par quoi les choses sont éclairées = clarté' [4], astre n.f.: 'corps céleste naturel visible' [ibid.] étoile n.f.: 'tout astre visible, excepté le Soleil et la Lune; point brillant 
dans le ciel, la nuit = astre' [ibid.], clarté n.f.: 'lumière qui rend les objets visibles d'une façon nette et distincte $=$ lueur, nitescence' [ibid.], прикметників pâle adj.: 'qui a peu d'éclat $=$ doux, faible' [ibid.], bleuâtre adj.: 'qui tire sur le bleu, n'est pas franchement bleu' [ibid.], lumineux adj.: 'qui a beaucoup de clarté, de lucidité' [ibid.] і дієслова éclairer v.tr.: 'répandre de la lumière (naturelle ou artificielle) sur (qqch. ou qqn)' [ibid.] з інваріантним значенням текстової одиниці création n.f.: 'action de donner l'existence, de tirer du néant $=$ genèse $=$ commencement, origine' [ibid.].

У цьому разі в сонній візії персонажа простежуємо алюзію на творення Світу: les premiers germes de la création; cette ébauche de création, у ході якої має місце проиес утрати власної iдентичності як найбільш виразного прояву психічного розладу письменника [5, с. 27-29], що в оповіді вербалізовано неіснуванням власного тіла (j'avais un corps aussi étrange) й потрактовуваннями себе невід'ємною частиною химерних створінь, справжніх велетнів. Конотативне значення іменника monstre n.m.: 'chose bizarre, incohérente, formée de parties disparates' [4] актуалізує у цьому разі світ сновидінь $i$ сонних візій, в якому все видається неможливим і фантастичним, оскільки des monstres changeaient de forme, et dépouillant leurs premières peaux, se dressaient plus puissants sous des pattes gigantesques (“дивні створіння змінювали свою форму, знімаючи з себе верхній шар шкіри, а з лапами величезних розмірів вони ставали ще сильнішими").

Такі фантастичні (не)можливі світи стали однією із визначальних тенденцій художньої літератури XIX ст. [5, с. 27]. На думку французького текстолога П'єра Кастекса, неможливі, в тому числі й оніричні світи, творяться завдяки таким референтним фізіологічним або емоційним станам людини, як сон, боязнь, сп'яніння, емочійне чи психічне перезбудження, докори сумління, й іншим патологічним і нездоровим проявам організму, що підсилюються ілюзіями, страхами й маренням [3, с.6]. При цьому основними персонажами в таких фантастичних мікрокосмах виступають, як правило, безликі, самотні істоти 3 майже невизначеною ідентичністю, що корелюють у цьому разі з фантомами / ілюзіями / химерами як суб'єктивно забарвленими екзистенціями й галюцинаціями, котрі виникають у психічно неврівноважених і хворих особистостей, таких як шизофреніки, параноїки та психастеніки [5, с. 37-38]:

$\diamond$ Ce ne fut cependant qu'un évanouissement, après lequel j'eus encore la force de regagner ma demeure pour me mettre au lit. La fièvre s'empara de moi; en me rappelant de quel point j'étais tombé, je me souvins que la vue que j'avais admirée donnait sur un cimetière, celui même où se trouvait le tombeau d'Aurélia. <> Je n'eus d'abord que des rêves confus, mêlés de scènes sanglantes. Il semblait que toute une race fatale se fût déchaînée au milieu du monde idéal que j'avais vu autrefois et dont elle était la reine (Nerval, p. 42-43).

Приміром, у наведеному вище уривку текстовими знаками світу божевілля як результату хворобливого стану персонажа постають іменники évanouissement n.m. як такий фізіологічний стан людини, котрий близький до іï несвідомого буття: 'le fait de perdre connaissance; perte momentanée et complète de la conscience, de la sensibilité et de la motilité, accompagnée d'un affaiblissement des battements cardiaques et d'un ralentissement de la respiration' [4] тa fièvre n.f.: 'élévation anormale de la température du corps = hyperthermie' [ibid.], що може виступати тут проявом надмірного емоиійного перезбудження: "vive agitation, état passionné = agitation, éréthisme, exaltation, excitation, fébrilité' [ibid.]. У поєднанні з дієсловом s'emparer v.pron.: 'se rendre maitre (d'un esprit, d'une personne) au point de dominer, de subjuguer = envahir, gagner' [ibid.] останній позначає повну й беззаперечну втрату відчуття реальності й готовність головного героя перейти до іншого, квазіреального світу його буття (світ сновидінь і сонних візій).

Висновки. Вважаємо, що цілком правомірно стверджувати, що оніричні лексеми в аналізованому творі, тобто іменники rêve n.m., rêverie n.f., sommeil n.m., image n.f., pensée n.f., délire n.m., imagination n.f., mort n.f., illusion n.f., vision n.f., abrutissement n.m., néant n.m., perception n.f., pressentiment n.m.; прикметники infini adj., navrant adj., insensé adj., bizarre adj., sensible adj., invisible adj., confus adj., surnaturel adj.; дієслова éprouver v.tr., sentir v.tr.; іменникові та дієслівні конструкції avoir le sentiment, voir des images, épanchement du songe, faire un rêve, il semblait, віддзеркалюють світобачення і світовідчування французького письменника крізь призму сну, що постає окремим осередком культури, котрий ми маємо змогу виявити у мові [18, с. 59]. 
Трактування сну як емерджентної альтернативної реальності, а також його витлумачення як специфічного стану свідомості властиве мистецтву здавен і дотепер [13, с. 10]. У лінгвонаративній поетиці Жерара де Нерваля сон, а разом із ним і сонні візї̈ та сновидіння не лише маркують і текстуалізують особливу “персонажну інореальність" [9, с. 224] як його своєрідну оніричну подорож (le voyage onirique) [5, с. 27-28], а й виступають засобами самоаналізу й самопізнання, оскільки моделюють несвідомі суб'єктні авторські стани, зокрема змінені стани свідомості, перебування в яких подекуди наближається для французького письменника XIX століття до істинної й справжньої реальності.

Французький оніричний наратив XIX століття постає, таким чином, ментальним конструктом авторської ідентичності, створеним шляхом несвідомої, тобто інтуїтивної організації наративних прийомів, технік і тактик, а також засобів образно-стилістичної фігуративності, що вербалізують індивідуально-авторське світосприйняття та світовідчування.

References

1. Bahtin, Mihail. 1986. Literaturno-kriticheskie stati. Moskva: Hudozhestvennaya literatura.

2. Brazgovskaia, Elena. 2008. Jazyki i kody. Vvedenie v semiotiku kultury. Perm.

3. Castex, Pierre-George. 1947. Anthologie du conte fantastique. Paris: Librairie José Corti.

4. DLPRé. 1997. Le Petit Robert électronique. Paris: Bureau van Dijk.

5. Djavari, Mohammad-Hossein, Afkhami, Mehdi Nia, Daftarchi, Nasrin. 2013. "Fantastique et techniques textelles dans Aurélia de Gérard de Nerval”. Revue des Études de la Langue Française 9: 27- 40.

6. Dzhonson, Robert. 1996. Snovideniya i fantazii. Moskva: REFL-book; Kiev: Vakler.

7. FJS. 1999. Filosofskiy entsyklopedicheskiy slovar. Moskva: INFRA-M.

8. JM. 1996. Entsyklopediya misticizma. SPb.: Iz-vo "Literatura".

9. Kudriavceva, D. A. 2007. "Snovidenie kak sposob poznaniya inorealnosti (“Avrelija" Zh. de Nervalja)". Znanie. Ponimanie. Umenie 3: 223-227.

10. Lotman, Yuriy. 2000. Semiosfera. SPb.: "Iskusstvo-SPb".

11. Lotman, Yuriy. 1970. Struktura hudozhestvennogo teksta. Semioticheskie issledovanija po teorii iskusstva. Moskva: Iskusstvo.

12. Masi, Jacobo. 2004/2007. La mise en scène du double dans l'Aurélia de Nerval. http//:www.2.lingue.unibo.it

13. Mochernyuk, Nataliya. 2005. "Snovydinnya v poetytsi romantyzmu: chaso-prostorova specyfika". PhD diss., Lviv.

14. NDA. 1994. Nouveau Dictionnaire des auteurs. De tous les temps et de tous les pays. T. III. Paris: V. Bompiani et Editions R. Laffont.

15. Novikova, Anna. 2010. "Lingvisticheskiy analiz realizatsii vozmozhnyh mirov v hudozhestvennom tekste". $\mathrm{PhD}$ diss., Cheliabinsk.

16. Novikova, Anna. 2008. "Referentsialno-situativnyi analiz semantiki vozmozhnyh mirov". Vestnik Cheljabinskogo gosudarstvennogo universiteta 26 . http://cyberleninka.ru/article/n/referentsialno-situativnyy-analiz.

17. Selivanova, Olena. 2008. Suchasna lingvistyka: napryamy ta problemy. Poltava: Dovkillya-K.

18. Tkachenko, Olha. 2012. "Linhvokulturni vytoky ta rozvytok onirychnoi leksyky' (na materiali ukrayinskoyi, angliyskoyi ta latynskoyi mov)". PhD diss., Kyiv.

19. Shlegel, Fridrih. 1983. Estetika. Filosofia. Kritika. T. 2. Moskva: Iskusstvo.

\section{Ілюстративний матеріал}

20. Nerval, Gérard. 2014. Aurélia ou le rêve et la vie. Paris : Éditions Clasiques. [Source électronique]. - Mode d'accès: http://www.atramenta.net/lire/aurelia/2335/2\#oeuvre_page.

Савчук Руслана. Французский онирический нарратив: опыт лингвосемиотического анализа (на материале романа Ж. де Нерваля “Aurélia ou le rêve et la vie”). В статье представлены и проанализированы наиболее показательные лингвонарративные и лингвокогнитивные механизмы конструирования онирического повествования, присущие французскому художественному текстообразованию XIX века. Определение текстообразующего потенциала “измененных состояний сознания” как знаково-языковых структур отображения нарративных стратегий во французских художественных текстах дает возможность отследить динамику нарративного мышления писателей как представителей конкретной историко-культурной эпохи. Французские художественные тексты XIX века могут считаться такими образцами художественного мышления писателей, которые отображают общественные настроения каждой исторической эпохи, и именно поэтому их анализ необходим для реконструкции механизмов трансформации когнитивных структур в знаковые языковые формы. С целью определения приметных тенденций формирования и форматирования онирического нарратива указанного периода выяснены главные закономерности порождения и развертывания повествования в аспекте образностилистической фигуративности в плане семиозиса нарративных приемов, техник или тактик французского художественного текстообразования. С позиций лингвонарратологии, лингвосемиотики, а также с привлечением достижений семантики возможных миров и стилистики художественной речи, определено, что французское 
художественное текстообразование XIX века отличается конструированием и форматированием онирической повествовательной реальности, которая характеризируется множественностью, метафоричностью, фантастичностью и эмоционально-смысловой значимостью повествовательного изображения. С точки зрения лингвосемиотики исключительной особенностью французского художественного нарратива XIX века есть “измененные состояния сознания" писателя, выступающие референтами отображения и конструирования онирической повествовательной реальности. В статье определено, что французский онирический нарратив сконструирован в дискурсе снов и сонных визий гомодиегетического повествователя, который соотносится с языковой личностью самого французского писателя. Установлено, что в анализируемом романе “Aurélia ou le rêve et la vie” текстуальными средствами создания квазиреальности выступают онирические лексемы, а также многочисленные средства образно-стилистической фигуративности с семой 'мнимое / невозможное'.

Ключевые слова: онирический нарратив, онирическая повествовательная реальность, лингвосемиотика, французское художественное текстообразование, измененные состояния сознания.

Savchuk Ruslana. The French onieric Narrative Through Semiotic Analysis (on the Example of "Aurélia ou le rêve et la vie" by Gérard de Nerval). The present research paper has outlined and has analyzed the most revealing linguistic narrative and cognitive mechanisms of the oneiric narrative formatting, found in the $19^{\text {th }}$ century French fictional text formation. Exploring the text-forming potential of the "altered states of consciousness" as sign-language structures reflecting the narrative strategies in French prose works has allowed us to trace the dynamics of the writers' narrative thinking as the representatives of a particular historical and cultural era. The $19^{\text {th }}$ century French fictional texts are those examples of the writers' artistic thinking that reflect human beliefs, thoughts and feelings of each historical period and consequently, it analysis is necessary to reconstruct the mechanisms of the transformation of cognitive structures into sign language forms. For the purpose of determining the most noticeable trends in the oneiric narrative formation and formatting, the main regularities of generating and unfolding the narrative through stylistic figurativeness in terms of the semiosis of narrative techniques, techniques or tactics of the French fictional text formation have been clarified. From the standpoints of linguistics, semiotics, as well as the acquisition of semantics of possible worlds and stylistics, it has been singled out that the $19^{\text {th }}$ century French fictional text formation is distinguished by the construction and formatting of onieric narrative reality, characterized by the multiplicity of images. From the point of view of semiotic approach, the notable feature of the $19^{\text {th }}$ century French fictional text formation are the writer "altered states of consciousness", who act as referents of the reflection and construction of onieric narrative reality. The paper also has revealed that the French onieric narrative is constructed in the homodiegetic narrator discourse of dreams and dreamy visions that is related to the linguistic personality of the French writer himself. It has been established that in the novel "Aurélia ou le rêve et la vie", the textual means of creating the quasi-reality are onieric lexical units and numerous means of stylistic figurativeness with the seme of 'imaginary / impossible'.

Key words: onieric narrative, onierici narrative reality, semiotics, French fictional text formation, "altered states of consciousness".

DOI: https://doi.org/10.32782/2410-0927-2020-12-28

УДК 811.111 .142

Юрій Семенов, Ніна Дюканова

\section{ЗАСТОСУВАННЯ ФРАЗОВИХ БАНКІВ В АНГЛІЙСЬКИХ АКАДЕМІЧНИХ ТЕКСТАХ}

Стаття має на меті охарактеризувати таку інновацію, як «банк академічних фраз», а також можливості його застосування при написанні і/ або редагуванні англійської академічної прози. Йдеться, зокрема, про жанри наукової статті й дисертації. Концепція «банк академічних фраз» базується на підході до аналізу академічних текстів, запропонованому видатним британським лінгвістом Джоном Свейлсом (John Swales) у 1980 pp. Він виявив деякі риторичні звороти, а також «крок» як частину тексту, що виконує конкретну комунікативну функцію. Джон Свейлс прагнув показати специфіку, а також універсальний характер мови, яка при цьому використовується. «Крок» як одиниця риторичного аналізу вживається зараз як основна складова банку академічних фраз. Вважається, що сучасна академічна англійська мова містить значне фразеологічне нашарування. Банк академічних фраз складає загальний ресурс для науково-педагогічних працівників. Він спроможний надати їм фразеологічні компоненти, організовані за принципом головних розділів наукової статті або дисертації. Використання фразових банків допомагає авторам правильно організувати академічні роботи, вставляючи готові фрази туди, де це доцільно. У цій роботі предметом дослідження є стилістика та фразеологія науково-технічної прози відповідно до класичних розділів академічної роботи, а саме: Анотація, Вступ, Матеріали і Методи, Результати, Обговорення результатів роботи і Висновки. Викладено критерії добору фраз, придатних до застосування у фразових банках. Розглянуто питання плагіату при написанні академічних текстів. На конкретних прикладах проаналізовано особливості стилю науково-технічних документів, які знайшли своє відображення у фразових банках. Надано універсальні рекомендації щодо вживання

(С Семенов Ю., Дюканова Н., 2020 